\title{
Tension-Torsion Fatigue Tests on the proton Exchange membrane Nafion 115, used in fuel cells
}

\section{Ensayos de fatiga por tensión-torsión en la membrana de intercambio de protones Nafion 115, utilizada en las pilas de combustible}

DOI: $10.46932 / \mathrm{sfjdv2n5-037}$

Received in: Oct 1st, 2021

Accepted in: Dec 30th, 2021

Gonzalo Mariano Domínguez Almaraz

Ph.D. in Energetics from the Uniersity of Poitiers, France

University of Michoacan (UMSNH) - Mexico

Facultad de Ing. Mecánica, Santiago Tapia No. 403, Col. Centro, Morelia, Mexico

E-mail: dalmaraz@umich.mx

Luis Miguel Torres Duarte

Ph.D. in Mechanical Engineering, University of Michoacan, Mexico

University of Michoacan (UMSNH) - Mexico

Facultad de Ing. Mecánica, Santiago Tapia No. 403, Col. Centro, Morelia, Mexico

E-mail: lmtorres@umich.mx

Christian Jesús Torres Pacheco

Ph.D. student, University of Michoacan, Mexico

University of Michoacan (UMSNH) - Mexico

Facultad de Ing. Mecánica, Santiago Tapia No. 403, Col. Centro, Morelia, Mexico

E-mail: cristian.torres@umich.mx

\begin{abstract}
Fatigue tests under tension-torsion have been carried out on the membrane Nafion 115 (Perfluorosulfonic acid, PFSA). This polymeric material is a main component to construct fuel cells, used as proton exchange membrane. These membranes undergo mechanical loading of tension and torsion during its industrial life. A self-designed machine has been constructed to obtain the fatigue endurance on this polymeric material under tension-torsion and the following conditions: one magnitude for the torsion angle, five initial tensile stresses, room temperature, and environmental relative humidity, and frequency of $1.6 \mathrm{~Hz}$. The experimental results show that fatigue endurance decreases with the increase of tensile stress when the torsion angle remains constant, as well as temperature and relative humidity (both taken at environmental conditions). Fracture surfaces were analyzed by SEM, in order to investigate the principal trends of crack initiation and propagation under this modality of fatigue loading.
\end{abstract}

Keyword: Nafion 115, Fuel cells, Tension-torsion, Fatigue resistance, Fracture surfaces.

\section{RESUMEN}

Se han realizado ensayos de fatiga bajo tensión-torsión en la membrana Nafion 115 (ácido perfluorosulfónico, PFSA). Este material polimérico es un componente principal para la construcción de pilas de combustible, utilizado como membrana de intercambio de protones. Estas membranas se someten a cargas mecánicas de tensión y torsión durante su vida industrial. Se ha construido una máquina de diseño propio para obtener la resistencia a la fatiga de este material polimérico bajo tensión-torsión y en las 
siguientes condiciones: una magnitud para el ángulo de torsión, cinco tensiones iniciales de tracción, temperatura ambiente y humedad relativa ambiental, y frecuencia de 1,6 Hz. Los resultados experimentales muestran que la resistencia a la fatiga disminuye con el aumento de la tensión de tracción cuando el ángulo de torsión se mantiene constante, así como la temperatura y la humedad relativa (ambas tomadas en condiciones ambientales). Las superficies de fractura fueron analizadas por SEM, con el fin de investigar las principales tendencias de iniciación y propagación de grietas bajo esta modalidad de carga de fatiga.

Palabra clave: Nafion 115, Pilas de combustible, Tensión-torsión, Resistencia a la fatiga, Superficies de fractura.

\section{INTRODUCTION}

Proton exchange membranes (PEM), destined to fuel cells have been introduced at the end of last century [1-3], as electrolytes of new sources for clean renewable energy and electricity production [4]. Even if the physicochemical properties of these materials have been studied the last 25 years [5, 6], the mechanical properties of PEM have been less analyzed and understood [7, 8].

During use in fuel cells, PEMs may undergo mechanical loading, which include tension and torsion; nevertheless, very limited studies have been conducted in this matter in the knowledge of the authors. The durability is one of main problems for polymers used as PEM; in turn, this is related to thermic, physicochemical and mechanical loading [9,10]. Furthermore, the mechanical behavior of PEM is highly dependent on the loading magnitude and rate, as well as temperature $[11,12$. Mechanical loading in PEMs induces damage by sliding, bond rotation and entanglements or cross-links at the scale of polymeric chains [13], and it is well recognized that elastic modulus and yield strength of PEMs decrease notably with temperature and less with humidity $[14,15]$. Since the use of Nafion 115 as PEMs is subjected to different loading, including tension and torsion, temperature, humidity and ultraviolet rays, it is of main interest to carry out mechanical testing to assess its behavior in fuel cells.

\section{MATERIALS AND METHODS}

\subsection{MATERIALS}

Polymeric material Nafion 115 was obtained from the Fuell Cell Store society, College Station, Texas, USA. Rectangular strips of this polymer were used for experimental tests of tension-torsion; Figure 1 shows the dimensions $(\mathrm{mm})$ of testing strips. 
Figure 1. Dimensions (mm) of the experimental Nafion 115 strip and image. 0.127 thickness

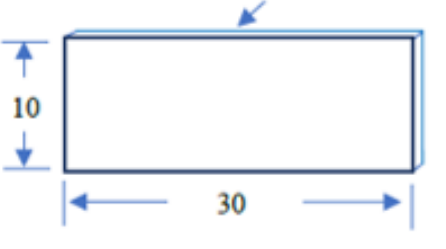

a)

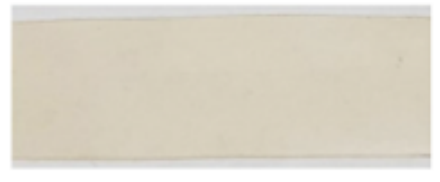

b)

In Table 1 are listed the main physical and mechanical properties of tested Nafion 115.

Table 1: Main physical-mechanical properties of Nafion 115

\begin{tabular}{|l|l|}
\hline Specific Gravity & 1.98 \\
\hline Basis Weight $250 \mathrm{~g} / \mathrm{m} 2$ & $250 \mathrm{~g} / \mathrm{m}^{2}$ \\
\hline Tensile Modulus $\left(50 \% \mathrm{RH}, 23^{\circ} \mathrm{C}\right)$ & $249 \mathrm{MPa}$ \\
\hline Tensile Strength $\left(50 \% \mathrm{RH}, 23^{\circ} \mathrm{C}\right)$ & $43 \mathrm{MPa}$ \\
\hline Elongation at Break, $\%\left(50 \% \mathrm{RH}, 23^{\circ} \mathrm{C}\right)$ & 225 \\
\hline Tear Resistance - Initial $\left(50 \% \mathrm{RH}, 23^{\circ} \mathrm{C}\right)$ & $6000 \mathrm{~g} / \mathrm{mm}$ \\
\hline Tear Resistance - propagating $\left(50 \% \mathrm{RH}, 23^{\circ} \mathrm{C}\right)$ & $>100 \mathrm{~g} / \mathrm{mm}$ \\
\hline
\end{tabular}

\subsection{EXPERIMENTAL PROCEDURE AND TEST APPARATUS}

A new self-designed and constructed device was used to carry out the tension-torsion experimental tests; a general description is as follows:

1) An acrylic box (1) with dimensions: $20 \times 15 \times 15 \mathrm{~cm}$ as shown in Figure 2, contains different elements destined to carry out the experimental tests.

2) Three motors working under programmed steps are employed to impose longitudinal (2) and torsional (2') movement with the precision of $\pm 4 \square \mathrm{m}$ in longitudinal motion and \pm 0.1 degrees in torsion.

3) Three thermocouple heaters (3), are destined to control temperature during experimental tests, inside the acrylic box.

4) A Nafion 115 testing specimen (4), is clamped (10 $\mathrm{mm}$ of each side) by the two jaws (5), connected to two rotation step motors.

5) A load cell (not shown), is destined to measure the applied tensile stress on the Nafion 115 strip.

6) A temperature and humidity sensor (6), is used to measure the imposed environmental temperature and humidity. 
Figure 2: Acrylic box and principal elements to carry out tension-torsion on the Nafion 115 strip

(3)

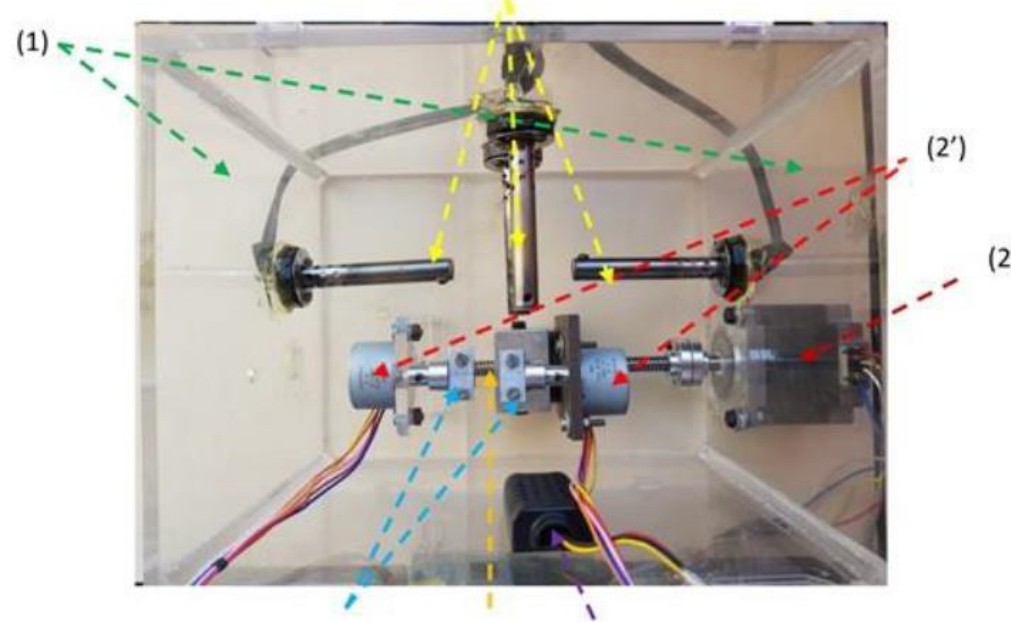

(5) (4) (6)

\subsection{CALIBRATION OF TENSILE DISPLACEMENTS}

To perform a correct calibration between the motor steps and the linear displacement of the membrane, displacement measurements were made using an inductive displacement sensor of the GPX series with a linearity error of $\pm 0.3 \%$ F.S. Figure 3 shows the sensor used for the actual measurement of the linear displacements generated by each step of the NEMA 23 motor.

Figure 3. Inductive displacement sensor for calibration of linear displacements of the NEMA 23 motor.

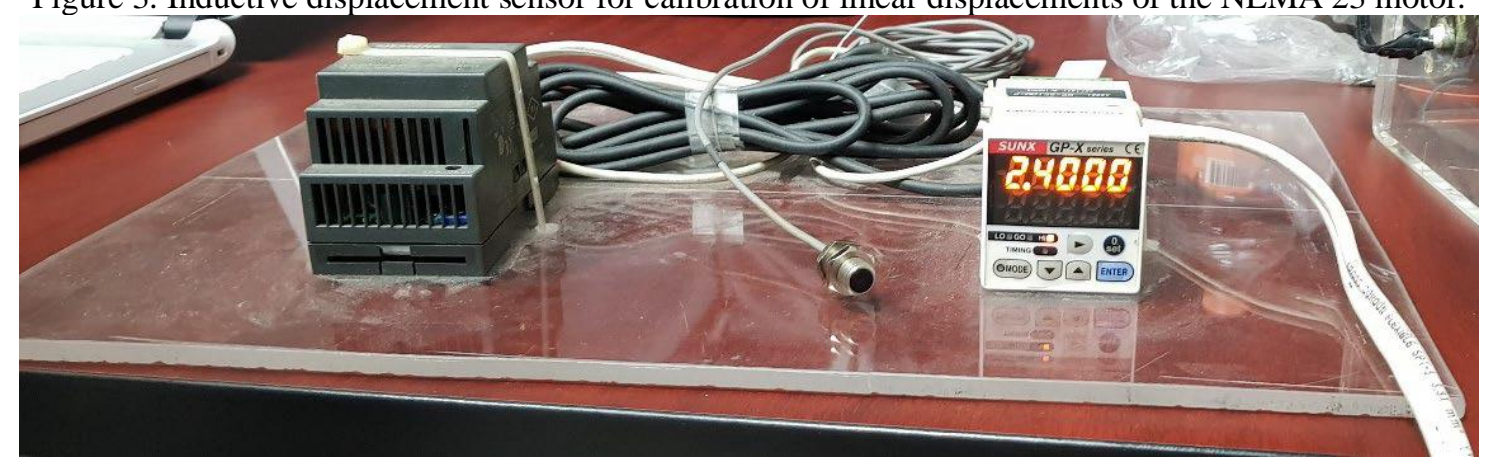

In Figure 4 is shown the arrangement of the sensor (in the membrane fastener) in a place suitable for a correct reading of the displacement. On the opposite side of the sensor, metal elements were placed that serve as a reference to the internal electromagnetic field of the sensor for its operation (for the reading of the displacements). 
Figure 4. Placement of the inductive sensor to measure the displacements generated by the NEMA 23 motor.

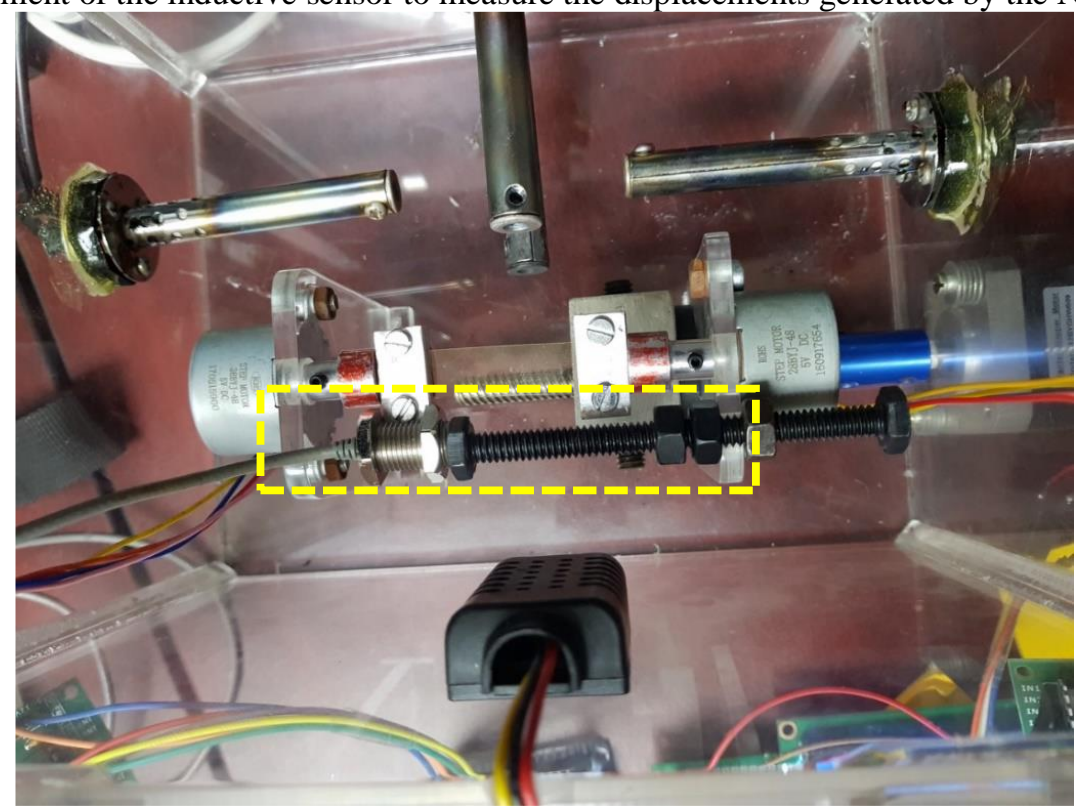

\section{EXPERIMENTAL RESULTS}

\subsection{TENSILE RESULTS}

The first experimental tests were carried out to evaluate the stress-strain curve on this polymeric material at room temperature and $50 \%$ of relative humidity. Applied steps motor for tensile displacement was used for this purpose: 10 steps in the motor represented $1500 \square \mathrm{m}$ of longitudinal displacement in the Nafion 115 strip, and approximately 11.2 MPa of maximum tensile stress. In Figure 5 is plotted the stressstrain curve obtained from experimental tests for this material. The experimental points plotted in Figure 5 are the average of 5 experimental tests. Linear behavior is observed for an applied tensile load of as high as $20 \mathrm{MPa}$ and deformation of about $8-9 \%$.

Figure 5. Stress-Strain curve obtained experimentally (points), and projection (dotted line), for Nafion 115.

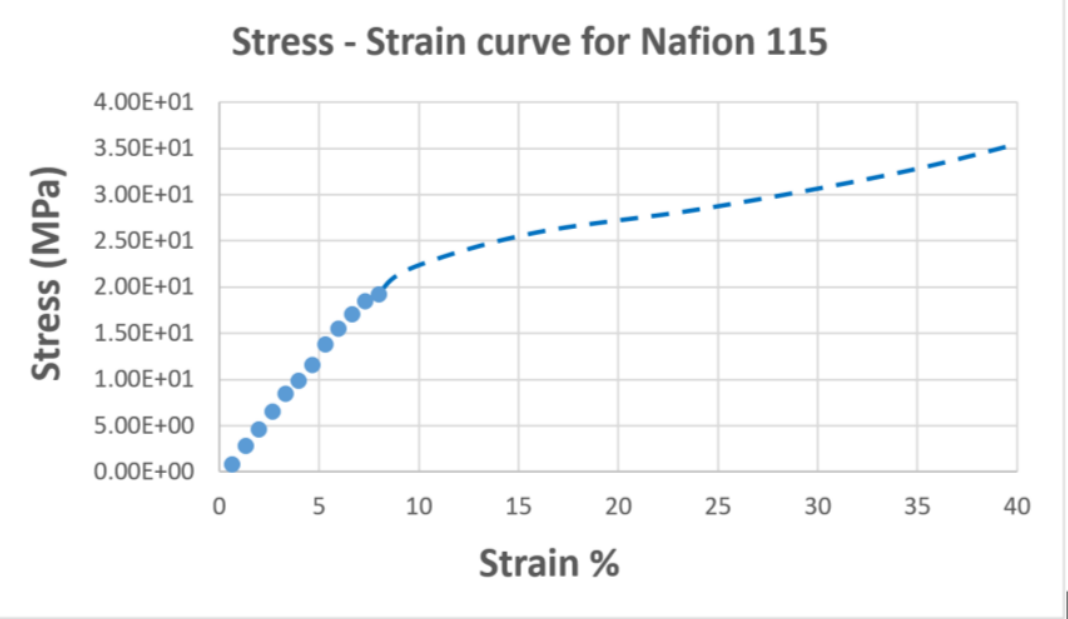




\subsection{FATIGUE ENDURANCE RESULTS}

In Figure 6 are plotted the experimental results of tension-torsion on the Nafion 115 strip. The experimental parameters were: constant torsion angle of 50 degrees ( 25 degrees induced by the first torsion step motor in one direction and 25 degrees in the opposite direction induced by the second torsion step motor), $25^{\circ} \mathrm{C}$ of room temperature, relative humidity of $50 \%$, frequency of $1.6 \mathrm{~Hz}$ and loading rate $R=-1$. The vertical axis of this graph represents the static tensile stress applied to the Nafion 115 strip and the horizontal axis the number of cycles of fatigue life under the described loading conditions. Five tensile loads were used for fatigue tests: 60, 55, 50, 45 and $40 \mathrm{MPa}$, as shown in Figure 6.

Figure 6. Fatigue endurance results for the Nafion 115 strip, under tension-torsion tests and environmental conditions.

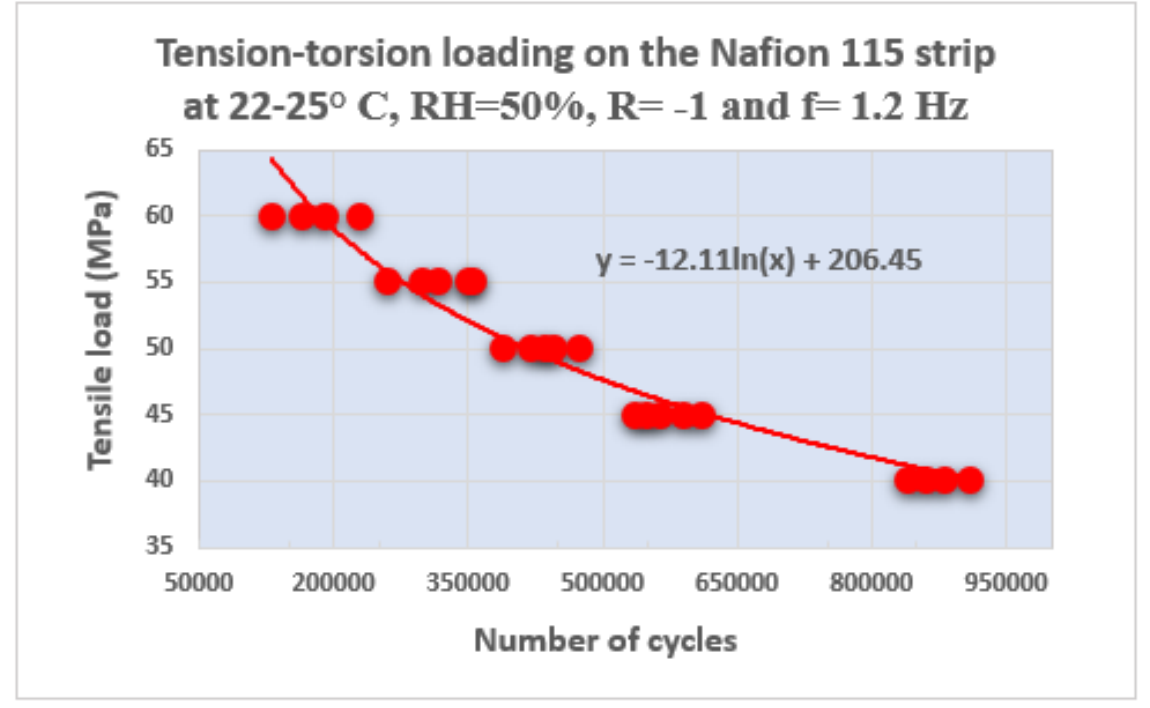

\subsection{CRACK INITIATION AND PROPAGATION ON NAFION 115, UNDER THE DESCRIBED LOADING CONDITIONS}

Figure 7. Fracture of the Nafion 115 strip under tension-torsion loading
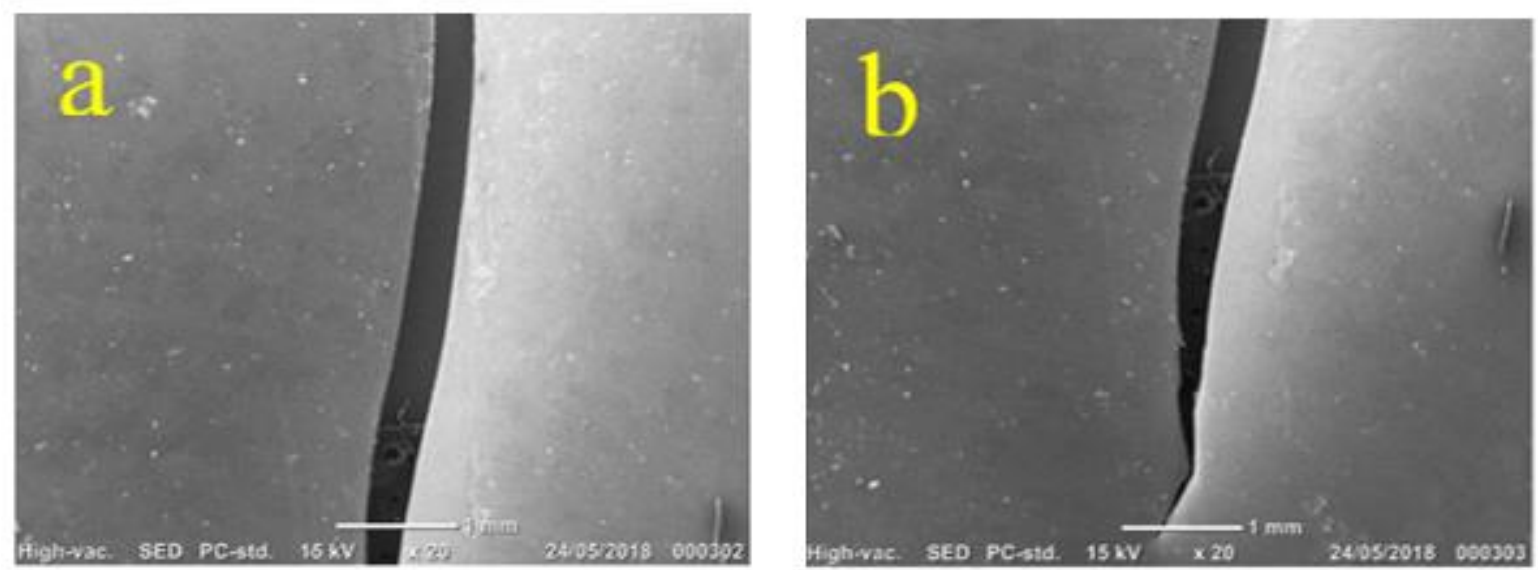
Figure 7 illustrates the fracture trends under this modality of loading on the polymeric strip. Fracture initiation presents two trends: at one corner of the strip where this polymeric material is fastened by the metallic jaws; at this zone is localized the highest stress under tension.

The second site of crack initiation is localized close to the center of the specimen, where the combination of tension and torsion induces stress concentration. Fracture initiation is charaterized by a crack path quasi perpendicular to tensile stress, Figure 6a; whereas crack propagates with a bifurcation path when it attains $4.5 \mathrm{~mm}$ of propagation approximately, as illustrated in Figure 6b. The last behavior should be associated with torsion loading, which induces a variation on the path propagation when crack attains a specific length: the mode I of crack propagation is modified to mode II. In addition, this indicated that the maximum hoop stress criterion of Erdogan and Sih [16], governed the crack initiation and propagation in these fatigue tensile-torsion tests.

\section{DISCUSSION}

The static stress-strain curve of Figure 5 presents values higher compared to previous tensile tests carried out on this material [17]. The Nafion strip thickness may related to this discrepancy: $127 \square \mathrm{m}$ in the present work, $25 \square \mathrm{m}$ in the referred work, leading to a factor of 3 approximately. In addition, density and rigidity of cross-linked polymeric chains may contribute to this behavior [18]. Concerning the fatigue endurance results, tension-torsion results show a decreasing behavior when the static tensile load increases, at constant torsion angle of 50 degrees. Experimental results show that fatigue endurance is close to 200,000 cycles when the tensile load is $60 \mathrm{MPa}$; this value increases close to 900,000 cycles for tensile load of $40 \mathrm{MPa}$. A logarithmic regression curve is obatined from the experimental points for the evolution of fatigue endurance under the described loading consitions, which is plotted in Figure 6. Concerning the fracture trends, the tension-torsion loading on this polymer induces a predominant mode I at the crack initiation; nevertheless, this behavior is modified when the mode I and II compite and generates transition when the rate: tensile fracturing stress/shear fracturing stress decreases to a critical value. The bifurcation observed in the crack path of fracture surfaces of this polymer, Figure $7 \mathrm{~b}$, is the physical evidence of such transition.

\section{Conclusions}

The following conclusions may be drawn from this work:

- $\quad$ Fatigue endurance has been obtained for the prtoton exchange membrane Nafion 115, under tension-torsion loading. 
- A new testing machine self-designed and constructed was implemented to obtain experimental fatigue results on the Nafion 115 strip, with control of tension and torsion loads, as well as temperature and humidity.

- $\quad$ The results presented in this study were obtained for a constant torsion angle, room temperature and relative humidity of $50 \%$, varying only the applied tensile stress.

- Logarithmic regression was used to obtain the tendency curve from the fatigue endurance experimental points.

- $\quad$ The dispersion of fatigue endurance results increases as the tensile applied load increases, for the range of applied tensile stress.

- The General trends for the crack initiation and propagation have been observed and described under the mentioned loading conditions.

\section{ACKNOWLEDGEMENTS}

The authors express their special mention of gratitude to CONACYT (The National Council for Science and Technology, Mexico), for the financial support destined to this study by the program grant: CB241117-2014. An additional mention of gratitude to the University of Michoacán in Mexico for the received support in the development of this work.

\section{CONFLICT OF INTEREST}

The authors declare that there is no conflict of interests in the publication of this paper. 


\section{REFERENCES}

[1] Millington, B., Shangfeng, D., Pollet, B.G. (2011). The effect of materials on proton exchange membrane fuel cell electrode performance, J. of Power Sources, 196(21) 9013-9017.

[2] Peighambardoust, S.J., Rowshanzamir, S. (2010). Review of the proton exchange membranes for fuel cell applications, Inter. J. of Hydrogen Energy, 35(17) 9349-9384.

[3] Aparicio, M., Lecoq, E., Castro, Y. et al. (2005). Proton Conducting Organic/Inorganic Sol-Gel Membranes Produced from Phenyltriethoxysilane and 3-Methacryloxypropyl Trimethoxysilane, J. SolGel Sci. Technol., 34 233-239.

[4] Nafil R.Q., Majeed M.S. Fuel Cells as a Source of Green Energy. In: Vizureanu P., editor. Thermodynamics and Energy Engineering. Intech; London, UK: 2020.

[5] Wee, J.-H. (2007). Applications of proton exchange membrane fuel cell systems, Renew. \& Sustain. Ene. Revi., 11 1720-1738.

[6] Moore, A., Huang, X., R. Jiang, P.J. (2018). High fidelity model for proton exchange membrane fuel cell power module considering internal power losses, Fuel Cells, 18(1) 63-72.

[7] Dachuan Y., Yuvarajan, S. (2005). Electronic circuit model for proton exchange membrane fuel cells, J, of Pow. Sources, 142(1-2) 238-242.

[8] Pratt, J.W., Klebanoff, L.E., Munoz-Ramos, K., Akhil, A.A., Curgus, D.B., Schenkman, B.L. (2013). Proton exchange membrane fuel cell systems for airplane auxiliary power, App. Energy 101, 776.

[9] ] Hickner, M.A., Pivovar, B.S. (2005). The chemical and structural nature of proton exchange membrane fuel cell properties, Fuel Cells, Poly. Membr. I, 5(2) 201-212.

[10] Yang,Ch., Srinivasan, S., Bocarsly, A.B., Tulyani, S. J., Benziger, B. (2004). A comparison of physical properties and fuel cell performance of Nafion and zirconium phosphate/Nafion composite membranes, J. of Membrane Science, 237 145-161.

[11] Chen, F., Yu, Y., Gao,Y. (2017). Temperature control for proton exchange membrane fuel cell based on current constraint with consideration of limited cooling capacity, Fuel Cells, 17 (5) 662-670.

[12] Zhang, T., Wang, P., Chen, H., Pei, P. (2018). A review of automotive proton exchange membrane fuel cell degradation under start-stop operating condition, App. Energy 223(C) 249-262.

[13] Caruso, M.M., Douglas, D.A., Shen, Q., Odom, S.A., . Sottos, N.R,, White, R.S., Moore, J.S. (2009). Mechanically-Induced chemical changes in polymeric materials, Chemi. Revie. 109(11) 5755-5798.

[14] Satterfield, M.B,, Majsztrik, P.W., Ota, H., Bezinger, J.B., Bocarsly, A.B. (2006). Mechanical properties of Nafion and titania/Nafion composite membranes for polymer electrolyte membrane fuel cells, J. of Polymer Science-B: Polymer Physics, 44(16) 2327-2345. 
[15] Alavijeh,,A.S., Goulet, M.A., Khorasany,,R.M.H., Ghataurah, J., Lim, C., Lauritzen, M., Kjeang, E., Wang, G.G., Rajapakse, R.K.N.D. (2015). Decay in mechanical properties of catalyst coated membranes subjected to combined chemical and mechanical membrane degradation, Fuel Cells, 15(1) 204-213.

[16] Chao, Y.J., Liu, S. (1997). On the failure of cracks under mixed-mode loads, Int. J. of Fracture, 87 201-223.

[17]Khorasany, R.M.H., Alavijeh, A.S., Kjeang, E., Wang, G.G., Rajapakse, R.K.N.D. (2015). Mechanical degradation of fuel cell membranes under fatigue fracture tests, J. of Pow. Sour., 15 12081216.

[18] Kumari, M., . Sodaye, H.S., Sen, D., Bindal, R.C. (2018). Properties and morphology studies of proton exchange membranes based on cross-linked sulfonated poly (ether ether ketone) for electrochemical application: Effect of cross-linker chain length, Sol. Sta. Ionics, 316 75-84. 